\title{
FIRST DO HARM! A MEDICAL EXPERIMENT ON AUSTRALIAN PRISONERS OF WAR AND THE CAREER OF A MILITARY PHYSICIAN
}

\author{
Konrad Kwiet and George Weisz
}

\section{Introduction}

On May 20, 1941, the Wehrmacht launched Operation Merkur-the largescale airborne invasion of the Greek island of Crete. ${ }^{1}$ It was the first of its kind in the history of warfare. The fierce battle between German parachutists and glider-borne infantry, and the Allied "Creforce," lasted 12 days, each side suffering severe losses. Thousands of soldiers were killed, injured or went missing in action: Germans and Austrians, Britons, Australians and New Zealanders, Greeks and Cypriots, Palestinians and Indians. More than 16,000 Empire troops were taken prisoner, among them 3,109 Australians, almost half the Australians deployed on Crete, ${ }^{2}$ and more than one-third of those captured by the Axis powers in Europe during World War Two. ${ }^{3}$ The defeat at Crete was Australia's "largest single catastrophe of the war, surpassed only by the fall of Singapore in February 1942."4 Despite extensive research on the military campaign, one incident on the sidelines has, to date, evaded notice: five Australian prisoners of war (POWs) on Crete who were exposed in the summer of 1941 to a hepatitis experiment, ${ }^{5}$ presumably the first recorded case in

\footnotetext{
1 Peter Monteath, P.O.W.: Australian Prisoners of War in Hitler's Reich (Sydney: Pan Macmillan Australia, 2001), 75 .

2 Ibid., 78.

3 Australian War Memorial Encyclopedia, https://www.awm.gov.au/encyclopedia/pow/ww2.

4 Joan Beaumont, “Introduction,” in Australia's War 1939-1945, ed. Joan Beaumont (Sydney: Allen \& Unwin, 1996), 12.

5 George Weisz was the first to access and evaluate the personal open files of the Australian POWs housed at the National Archives of Australia. He published his findings in a short article, George Weisz, "Nazi Medical Experiments on Australian Prisoners of War: Commentary on the Testimony of an Australian Soldier," Journal of Law and Medicine 23, no. 2 (2015), 457-59. The article attracted considerable media attention in Australia and abroad. Konrad Kwiet joined the project, searching for records in German archival depositories on the career of the military physician who conducted the medical experiment. Weisz, a surgeon, dealt with the medical dimension. Kwiet, a historian, constructed the historical narrative. We would like to sincerely thank friends and colleagues who assisted us in researching this case study: Clement Boughton, Klaus Toyka, Paul J. Weindling, Giles Bennett, Astrid Ley, Rüdiger Overmans, Jürgen Förster, Sarah Haid, Joachim Schneeweiss, Beate Winzer and Jane Sydenham-Kwiet.
} 
Australian history. They belong to the forgotten victims and survivors of murderous Nazi medicine. ${ }^{6}$

At the core of this contribution stands a review of the life history of Friedrich Meythaler, and a critical assessment of a hepatitis experiment he conducted during the Second World War. Meythaler was an eminent physician whose career illustrates the easy transition, indeed the continuity, from Nazi medicine to medicine in post-war Germany.

Our research is ongoing as there are still many gaps in the known history to be filled. One key question that remains is whether Meythaler's medical experimentation had long-term effects on the health of the POWs who served as his test subjects. Privacy regulations restrict access to patient records that may be held at hospitals, insurance companies and clinics. In addition, more research needs to be conducted to shed light on the medical and institutional networks of the Nazi regimes within which Meythaler was operating. ${ }^{7}$ Furthermore, there is evidence to suggest that Meythaler's experiment represents only the tip of the iceberg. Many more POWs from Australia and other Allied countries, held in custody of the German Wehrmacht, might have been selected for human experiments conducted by Nazi doctors.

For the Cretan population, Nazi rule and terror commenced in May 1941. From the outset, the occupying military authorities implemented examples of their extermination policies. Instructed by Hermann Göring, Commander-inChief of the Luftwaffe, General Kurt Student, commander of the XI Fliegerkorps, issued an order to his men to "annihilate" civilians in retaliation for local resistance-immediately and without any judicial proceedings. ${ }^{8}$ On June 2, parachutists arrived in Kondomari to slaughter 50 men. The following day a firing squad perpetrated another horrific war crime known as the "Holocaust of Kandano.” 180 civilians were massacred and all buildings were dynamited or torched and the village razed to the ground. The murder site was declared a "dead zone." War crimes committed by the Wehrmacht continued unabated in the course of "pacifying" the conquered island. ${ }^{9}$ The fate of the small, ancient

6 Paul J. Weindling, Victims and Survivors of Human Experiments: Science and Suffering in the Holocaust (London: Bloomsbury Academic, 2015).

7 Beate Winzer's PhD explores the history of the Luftmedizinische Forschungsinstitut der Luftwaffe, 1934-1945, to be submitted at the University Berlin Charitě. We thank her for bringing this military research centre to our attention, and providing us with details of the military and medical networks.

8 Detlef Vogel, “Das Eingreifen Deutschlands auf dem Balkan,” in Das Deutsche Reich und der Zweite Weltkrieg, Bd.3 Der Mittelmeerraum und Südosteuropa, ed. Militärgeschichtliches Forschungamt (Stuttgart: Deutsche Verlags-Anstalt, 1984), 508.

9 Norman Paech, “Wehrmachtsverbrechen in Griechenland,” Kritische Justiz 3 (1999), 380-97; Christian Hartmann, Johannes Hürter, Ulrike Jureit, Jan Philipp Reemtsma and Horst Möller, Verbrechen der Wehrmacht: Bilanz einer Debatte (München: C.H. Beck, 2005). 
Jewish community of Crete was sealed three years later. On May 29, 1944, about 300 Jews were rounded up, destined for Auschwitz. They were transported under appalling conditions to the port city of Heraklion and forced to embark the ill-fated Tanais, together with 400 Greek hostages and 800 Italian POWs. The boat was torpedoed by a British submarine and sank within minutes. There were no survivors. Accused of war crimes, General Student was sentenced in 1947 to five years in prison. One year later he was set free. Members of the killing units were never tried.

Friedrich Meythaler also escaped criminal prosecution after the war. He held the rank of Oberstabsarzt (Surgeon Major) and headed a sanitation company. He also served as consulting physician to the 12th German army that operated in the Balkans; such positions were reserved for Germany and Austria's medical elite. Much has been written about the crimes perpetrated by Nazi doctors in concentration camps, about the forced sterilisation of more than 400,000 people and of the murder of more than 300,000 psychiatric inmates in mental institutions as part of the so-called “ Euthanasia” programme, code-named Aktion T4.

Little is known about the recruitment and activities of consulting physicians. ${ }^{10}$ With the beginning of the Second World War, university professors, Privatdozenten (post-doctoral university fellows) and other specialists were called up for military service. Recruitment and deployment, arrangements and monitoring were in hands of the Berlin-based Army Medical Inspectorate, its affiliated Military Medical Academy, and the Research Institute of the Airforce for Aviation Medicine, set up in Göring's Reich Ministry of Aviation. ${ }^{11}$ Consulting physicians were not only deployed at home in the military districts but were also assigned to army groups, offering their services in all war-relevant areas of medicine. Later, they examined the ever-increasing cases of shell shock, bedwetting, self-harm and suicide attempts among soldiers, and referred patients to the brutal military justice systems. ${ }^{12}$ They continued medical research behind front lines, prescribed cures and treat-

10 Karl Philipp Behrendt, Die Kriegschirurgie von 1939-1945 aus der Sicht der Behandelnden Chirugen des Heeres im Zweiten Weltkrieg (PhD thesis, Albert-Ludwig University, Freiburg, 2003). See also Jürgen Förster, "Ideological Warfare in Germany, 1919 to 1949," in Germany and the Second World War: Volume IX/ I: German Wartime Society 1939-1945: Politicization, Disintegration, and the Struggle for Survival (Oxford: Oxford University Press, 2008), 487-88.

11 See Alexander Neumann, Arzttum ist immer Kämpfertum: Die Heeressanitätsinspektion und das Amt "Chef des Wehrmachtssanitätswesen" im Zweiten Weltkrtieg (1939-1945) (Düsseldorf: Droste, 2005). See also Wolfgang Uwe Eckart, and Alexander Neumann Eckhart, eds., Medizin im Zweiten Weltkrieg: Militärmedizinische Praxis und medizinische Wissenschaft im “Totalen Krieg” (Paderborn: Schöningh, 2006).

12 See Gine Elsner and Gerhard Stuby, Wehrmachtsmedizin und Militärjustiz, Sachverständige im Zweiten Weltkrieg: Beratende Ärzte und Gutachter für die Kriegsgerichte der Wehrmacht (Hamburg: VSA, 2012). 
ments, and presented their findings at conferences. Medical experiments, in particular human experiments, were an integral part of their role. A directive for consulting physicians authorised the experiments: "In time of war unique opportunities for medical research present themselves. These opportunities must not be missed."13

Upon his arrival on Crete, Meythaler selected five healthy Australian POWs in the port city of Rethymno, located on the central north coast of the island, for a hepatitis experiment. Declared "sick," they were admitted to the local hospital where they were examined and x-rayed. Blood and urine tests were performed. They were then injected with the blood of highly suspected hepatitis-affected German soldiers, some with, others without jaundice. This non-consensual human-to-human blood injection for diagnostic purposes did not only constitute a war crime but a clear violation of the 1907 Hague and the 1929 Geneva Conventions on the treatment of POWs. It also contravened the spirit of the ancient Hippocratic Oath that imposes on doctors the duty, to use the popular phrase, "First do no harm!" or also described as: "Practice two things in your dealings with disease: either help or do not harm the patient!”14 Meythaler's experiment was harmful and painful. It was, of course, totally unacceptable, both professionally and ethically. Australian records, recently digitised in the National Archives, identify the Australian POWs and trace their military service. The personal dossiers comprising the Service and Casualty Forms, the Attestation Sheets, letters and reports, POW files and the Proceedings of Discharge provided the biographical data.

The victims were young, born between 1907 and 1920. They came from Sydney, Melbourne and Hobart, and grew up in a lower socio-economic environment, earning their living as labourers, a cook and grocery assistant. One was a Catholic, the others Anglicans. Two were married. They enlisted after the outbreak of the war and joined in the ranks of the 2nd and 5th Australian Infantry Battalions that fought with the 16th Brigade Composite Battalion on Crete. After being discharged from the Rethymno hospital, they returned to military captivity. One of them managed to escape-like so many Allied soldiers — and sought refuge in the Cretan hills sheltered by locals. The others had to wait some time before they were shipped to Thessaloniki and incarcerated 
in a transit camp. ${ }^{15}$ From there they embarked on a long and harrowing journey to Germany.

In March 1942, they arrived in the small city of Lamsdorf to be incarcerated in nearby Stalag VIII B, one of the largest POW camps that administered more than 100,000 prisoners of Allied nationalities. Subjected to harsh forced labour in mining, factories and railway construction, they were transferred to Arbeitskommandos, labour detachments, living and working outside the main camp. One test subject, WJL, belonged to the 242 Australian POWs who did not survive Hitler's Reich. ${ }^{16}$ The Germans informed the Australian military of his death on May 30, 1942, and dispatched his German POW card. It was marked with the red death symbol and the handwritten entry: "Auf der Flucht erschossen" ("shot while attempting to escape”). It was the standard phrase to disguise murder. WJL was buried by the Germans in the Krakow military cemetery-Row 8, Grave 13-and posthumously awarded with an Australian war service medal. The other three POWs returned to Australia and were discharged in 1945-1946 “on compassionate grounds.” None of them informed the authorities about their treatment at the Rethymno hospital, nor lodged a claim for compensation for long-term damages caused by the experiment. The grocery assistant applied in the early 1950s to the POW Memorial Trust for a grant on the basis of his "nervous disabilities" and "suffering from nervous strain."17

It was left to the Australian POW who had managed to escape from Crete in November 1941 to inform the Australian military about the medical experiments and the damage these had caused. Arriving in Melbourne in early August 1942, he experienced several symptom-free weeks, alternating with one or two weeks of fever. The attacks gradually became less frequent, but were accompanied by muscle pain and lower back pain. In September 1942 he was admitted to a military hospital in Melbourne and examined by military physicians. They were unable to confirm the initial suspected diagnosis of "typhus," "malaria” and "pyrexia of unknown origin,” but several doctors commented on the back pain and blood test results found abnormalities. ${ }^{18}$ After several examinations and interrogations, the classified findings and clinical

15 The OKW (Supreme Command of the Armed Forces) did not raise any objections to transporting British, Australian and New Zealand POWs to Germany. However, the OKW did not favour transporting Jews to Germany, instead suggesting that "they could remain on the Balkans and perhaps be deployed in war relevant work.” R 40.741. Letter OKW to Foreign Affairs, June 11, 1941.

16 Monteath, P.O.W., 414.

17 Research has yet to be conducted as to whether the test subjects applied in 1986 for compensation for harsh treatment in German camps. The scheme was set up by the Australian government in the wake of Nazi war crimes investigations and public debates.

18 A high reading of $10 \%$ Eosinophilia (normal 1-3\%). 
notes were submitted to higher military authorities. A Colonel of the Australian Military Forces who saw the report stated: "If true, and there seems no reasons to doubt the veracity, (the case) is one which merits any protest which can be lodged by Dep. Prisoner War." ${ }^{19}$ No protest was lodged. Instead, the Australian Army staff in London were instructed to take up "the matter . . . with the United Kingdom authorities." ${ }^{20}$ A report was dispatched; however, no record of any British response has yet been found. ${ }^{21}$ In Australia, the case was closed. Appearing before a Medical Board, the psychiatric examiner concluded: "Apart from the fact that he was rather underweight and mildly anxious about himself, he did not appear to be permanently invalidated by his alleged experiences."22 Discharged on "mild psychiatric grounds" the patient left behind a lengthy testimony of the events in Crete. ${ }^{23}$ Having lost a lot of weight, he described the hunger rations as minimal, one meal per day of "a handful of cooked beans and one slice of Greek bread" and a pint of water twice a day. He remembered in detail the arrival of a doctor who "approached me and turned up my upper eyelid." The doctor returned the next day and conducted an examination, x-ray of the chest, and blood and urine tests. "He then stated I was sick, conducted me to a ward, in which there were a number of German patients, and ordered me into one of the five beds that had been set apart in the ward. ... The same day the four other Australians ... were brought in.,24

He continued with his recollection of the experiment, and his testimony is worth quoting here at length:

On the following day we were again examined, temperature, pulse, and blood and urine tests. Later that day the doctor returned and withdrew half a syringeful of blood ... from the arm of the German patient in the room and immediately injected it into a vein of my arm, after first applying a tourniquet in my upper arm. The blood went into my arm without clotting. The other Australians received similar injections, but I do not know from whom the blood was taken, as I was not paying attention to them at that time. The following day the doctor returned and after the customary examinations, temperature, pulse, blood and urine he injected into the vein at the same

19 (G.A.S) Chronological Record of Movements; Medical case sheet, October 19, 1942; Letter AMF-Southern Command to DDMS Victoria, April 2, 1943.

20 Ibid., Department of the Army, minute paper, April 14, 1943.

21 Ibid., letter to Australian Army Staff in London, May 5, 1943.

22 (G.A.S), letter AMF-Southern Command to DDMS Victoria, April 2, 1943.

23 Ibid., statement, April 10, 1943.

24 Ibid. 
place in my arm a clear fluid. The others were similarly treated. Following this injection we all became, within the space of 24 hours, feverish with high pulses, and felt very sick. We were not provided with any medicine as relief, but every morning thereafter until the 10th day the doctor examined us - eyes, temperature, pulse, blood, urine, and prodded us and tested us for pains in various parts of our bodies. It seemed to me that he appeared to be disappointed on observing the colour of my urine. By the 10th day the fever and body pains had gradually subsided, and we were given a second injection of blood, on this occasion in the buttocks... . Two hours later we were all very ill, suffering all the discomfiture of the first attack, but to a greater degree. ... On the 11th day a clear fluid was injected into each of us and thereafter until the 18th day the procedure was the same ... except that several of my friends had a tube inserted into their stomach through their throats. $^{25}$

Importantly, he also stated that the Germans from whom the blood had been taken were all very sick and receiving medical treatment: "Several of them had a very yellow complexion, and one particularly was yellow in the eyes."

After three weeks the Australians started to recover. They knew they had been "used for experimental purposes." They protested their treatment both in hospital and to the military authorities upon their return to the POW camp. The escaped POW suffered for months with high fevers and pains, especially in the back, and cramps in the legs.

German records, accessed in several archival depositories, ${ }^{26}$ and the literature consulted, shed light on the career of Friedrich Meythaler. ${ }^{27}$ They document his deployment in Crete, the human experimentation, and support the validity and plausibility of the Australian POW's testimonial accounts. The clinical notes taken during the examinations and experiments have not come to light as yet. The findings, however, were made public in a lecture presented

25 (G.A.S), letter AMF-Southern Command to DDMS Victoria, April 10, 1943.

26 The archival studies were conducted in the Freiburg-based Military Archives of the Federal Archives, the Federal Archives in Berlin, the Political Archives of Foreign Affairs in Berlin, and in the State Archives Nuremberg.

27 Michael Buddrus and Sigrid Fritzlar, eds., Die Professoren der Universität Rostok im Dritten Reich: Ein biographishes Lexikon (Berlin: Walter de Gruyter, 2007), 277; Paul J. Weindling, Nazi Medicine and the Nuremberg Trials: From Medical War Crimes to Informed Consent (London: Palgrave Macmillan, 2006), 38; Paul J. Weindling, Victims and Survivors, 64-66; Brigitte Leyendecker and Burghard F. Klapp, "Deutsche Hepatitisforschung im Zweiten Weltkrieg," in Der Wert des Menschen: Medizin in Deutschland 1918-1945, eds. Christian Pross and Götz Aly (Berlin: Edition Hentrich, 1989), 261-93; also Brigitte Leyendecker and Burghard F. Klapp, “Hepatitis-Humanexperimente im Zweiten Weltkrieg,” Zeitschrift für die gesamte Hygiene 35, no. 12 (1989), 756-60. 
at a conference of military physicians, ${ }^{28}$ and in an article published in a medical journal in 1942.

Friedrich Meythaler came from a well-established middle-class family in which Christian values were cultivated. Born in 1898 in Offenburg, he attended high school at a Gymnasium in the final years of the Wilhelmine Empire. He then joined the army in World War One, fighting at the Western Front as a platoon leader. Decorated and discharged as Lieutenant in early 1919, he undertook his studies in medicine at the top universities of Heidelberg and Munich, graduating in record time in 1923 with distinction. His doctoral dissertation explored a special case of bleeding of the kidney. Meythaler embarked on a career within the university hospital's system, treating patients, teaching and researching, gradually climbing the hierarchical ladder from intern to registrar, station doctor to senior doctor, and finally to chief physician and medical superintendent. Specialising in internal medicine, he attained a post-doctoral qualification in 1933. Three years later he was awarded a special teaching assignment to lecture in the field of aviation medicine. This teaching position secured his integration into Göring's Research Institute for Aviation Medicine, paving the way for his later deployment to Crete and recruitment as consultant physician. Moreover, the Medical Faculty of Rostok University had emerged as one of the key centres for liver research. In 1939, on the eve of World War Two, Meythaler was awarded a professorial title.

Since the National Socialist seizure of power, Meythaler had witnessed the systematic expulsion of Jewish doctors, first from universities and hospitals, then from private practices. ${ }^{29}$ About 8,000 lost their positions; many found refuge in exile, but those who remained trapped in Nazi Germany fell victim to the programme of the "Final Solution." Non-Jewish physicians profited from the removal of Jewish doctors. After the war, facing a denazification tribunal, Meythaler recalled the names of Jewish doctors under whose guidance he had worked in the years of the Weimar Republic.

His affiliation with National Socialism was determined less by ideological convictions than by professional interests; joining Nazi organisations assisted him in cementing and enhancing his academic career. In November 1933 he joined the SA, Hitler's Stormtroopers, offering his services within the SA

\footnotetext{
28 Frederick Taylor, Exorcising Hitler: The Occupation and Denazification of Germany (London: Bloomsbury, 2011); Norbert Frei, Vergangenheitspolitik: Die Anfänge der Bundesrepublik Deutschland und die NS-Vergangenheit (Munich: C.H. Beck, 2012).

29 Avraham Barkai, From Boycott to Annihilation: The Economic Struggle of German Jews 1933-1939 (Hanover: University Press of New England, 1989); Marianne Kaplan, Between Dignity and Despair: Jewish Life in Nazi Germany (New York: Oxford University Press, 1998), 26; Günter Plum, "Wirtschaft und Erwerbsleben,” in Die Juden in Deutschland 1933-1945, ed. Wolfgang Benz (Munich: C.H. Beck, 1983), 268-313.
} 
Medical Corps. He then joined other organisations affiliated with the Nazi Party but it was only in May 1937 that he joined the NSDAP. The high party number $(4,403,603)$ allocated to him attests to his late entry. Unlike the infamous SS doctors engaged in barbaric medical experiments, he saw no need to apply for membership in Heinrich Himmler's SS.

On the eve of World War Two, Meythaler was called up for military service. As Internist of a Feldlazarett (Field Hospital) he participated in the German conquest of Poland. He might have been aware of the atrocities and murderous campaigns unleashed by SS and police units alongside ethnic Germans against Jews and "saboteurs," politicians, intellectuals and priests. By the end of 1939, the death toll amounted to more than 60,000. ${ }^{30}$ In May 1940 the Wehrmacht launched its Blitzkrieg (Lightning War) against countries in Western Europe. Meythaler took up a position at the Field Hospital of a newly established Waffen-SS Division-the infamous 3rd Panzer Division Totenkopf (Death's Head).

By the time Meythaler was selected to go to Crete he had developed a reputation as an authoritative figure in the fields of liver dysfunction and infectious diseases. He could point to an impressive list of 66 publications; at the end of the war the number had risen to 73, documenting ongoing research on hepatitis and diabetes and his new pioneering studies on malaria. The supervision of 25 doctoral dissertations and papers, submitted by his students and interns in the pre-war years, was equally remarkable. ${ }^{31}$ Undoubtedly, these academic credentials led to the assignment in Greece, where "Hepatitis sine Icterus," that is, hepatitis without but mostly in conjunction with jaundice, was rampant. German and Allied soldiers alike were severely affected by jaundice. On Crete they were admitted to field and local hospitals. Meythaler hastened to carry out research on the differential diagnosis of the Mediterranean diseases amongst the German soldiers, and their causes and prevention.

The findings were submitted to the Berlin-based Army Medical Inspectorate, ${ }^{32}$ along with all the other reports from consulting physicians. As the hepatitis epidemic spread across Europe, causing a major problem for the army, at many places efforts were undertaken to identify the agent of the infectious hepatitis via animal trials and person-to-person experiments. Kurt

30 Jürgen Matthäus, Jochen Böhler and Klaus-Michael Mallmann, eds., War, Pacification and Mass Murder, 1939: The Einsatzgruppen in Poland (Lanham MD: Rowman \& Littlefield 2014); Jochen Böhler, Auftakt zum Vernichtungskrieg: Die Wehrmacht in Poland 1939 (Frankfurt am Main: Fischer, 2006); Alexander B. Rossino, Hitler Strikes Poland: Blitzkrieg, Ideology and Atrocity (Lawrence: University Press of Kansas, 2003).

31 Friedrich Meythaler, "Die wissenschaftlichen Arbeiten von Prof. Dr. Meythaler und Liste der wissenschaftlichen Arbeiten der Assistenten und Liste der Dissertationen,” compiled on January 14, 1944.

32 Neumann, Arzttum ist Kämpfertum. 
Gutzeit played a vital role in this research. A member of the SS since 1933, he served as Consultant Internist at the Army Medical Inspectorate and ran a department of internal medicine at the Military Medical Academy. Initially he conducted an experiment on himself. Two assistants carried out non-consensual experiments. Hans Voigt infected psychiatric patients from a mental hospital in Breslau. Arnold Dohmen had permission from Heinrich Himmler to select 11 Jewish juveniles from Auschwitz and to expose them to a barbaric hepatitis experiment in the Sachsenhausen concentration camp. ${ }^{33}$

This hepatitis research illustrates that university-based Nazi doctors often took the initiative and determined the scope of the experiments. They competed against each other to be the first to discover the infectious nature of the rampant disease. They used all available sites for their experiments: POW camps and field hospitals, universities and research institutions, psychiatric wards and concentration camps. The International Committee of the Red Cross, entrusted with the task of monitoring experiments in POW camps and concentrations camps, "was a catastrophic failure" in this regard. ${ }^{34}$

Meythaler's findings were quickly published. In August 1942 his article appeared in the medical journal Klinische Wochenschrift. ${ }^{35}$ The timing and scope of the research were mentioned: "In summer and autumn of 1941 I had the opportunity to personally see on the Balkan, in Greece and Africa, a large number-around 2,500 — cases of hepatitis infectiosa and to observe the course of the disease."36 Outlining the results of his examinations, he then admitted the blood injection from hepatitis-infected soldiers. The central sentence reads in English as follows:

As the causative agent is unknown, I carried out on Crete transmission experiments through transfer of blood from person to person in a pre-ikterian condition. The result in three of the test persons was an elevation of the sedimentation, a decreased body reaction with initial increase in the body temperature and a distinct liver enlargement over an observation period of 8 days, but no appearance of jaundice. ${ }^{37}$

Meythaler repeated this statement when he gave the keynote address at a sci-

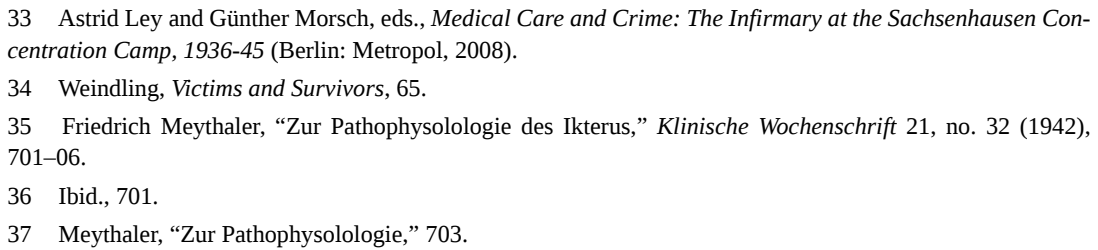


entific symposium in Athens on October 28, 1942. ${ }^{38}$ A newly established research centre was entrusted with the task of carrying out clinical examinations and medical experiments to combat the hepatitis epidemic. Research teams were sent from the Army Medical Inspectorate in Berlin, recruited by its consulting internist, Professor Gutzeit. Meythaler reiterated his findings:

There exists also a contagious infectious syndrome, a hepatitis infectiosa sine iktero. It can be assumed that it (hepatitis) is transmittable from human to human as well via experiments on animals. All hypotheses from clinical or experimental research point to a virus infection, whose agent has not been identified.

Meythaler's experiment can be evaluated as follows: he observed a febrile condition in a geographic region with numerous bacterial and parasitic infections. The illness appeared to result from a blood inoculation taken from sick German soldiers. Without documented blood group analyses in donors and recipients, the consequent illness could be either a transfusion reaction with blood group incompatibility or a rapid infection by a pathological agent. The rather short interval between blood transfer and the reactions of the recipients would imply an infectious illness with virtually no incubation period. This would be very unlikely with a viral infection like hepatitis A. The time interval would rather favour the interpretation of a transfusion reaction as indicated by hepatomegaly without jaundice. This led Meythaler to suggest blood-borne transmissibility of infectious hepatitis. That result had not yet been confirmed in laboratory tests. Other endemic infections ought to be taken into account:

a) The most likely alternative diagnosis was thought to be Malta Fever caused by the bacterium brucella mellitensis, which causes undulant fever attacks, lasting 10-14 days, of decreasing frequency and with persistent low-grade lumbar and muscular pain, corresponding to spondylitis (osteochondritis of the lumbar spine).

b) Malaria was excluded a year later in the Heidelberg Military Hospital.

c) Jaundice from either a viral infection, leptospirosis or spirochaetosis was not observed.

The five Australian POWs were seemingly used in a non-consensual, enforced experiment, probably in an ad hoc, ill-prepared attempt to diagnose the Ger- 
man soldiers' infection. The experiments were unscientific and inconclusive, a surprisingly poor quality experiment for an academic physician.

In December 1942 Meythaler returned to Germany to take up a professorship in internal medicine and a directorship of the outpatient clinic at the University of Erlangen, located in close proximity to Nuremberg. A link with the military was maintained. He was assigned to a sanitation unit and held in great esteem. In July 1944 the Medical Faculty of the University Halle ranked him first in line for a professorship. The Dean praised his academic credentials and emphasised his achievements as a military physician, saying "he excelled in this position, above all in the fight against malaria."39

Professorial candidates required the approval of the Nazi Party. Wolfgang Wagner, in charge of the political surveillance of the academic staff, did not raise any objections against his Party colleague. ${ }^{40}$ Meythaler remained in Erlangen. At the end of his Nazi career he was again called up as consulting physician against the background of the drastic shortage of doctors to look after female patients from Poland. They were incarcerated in a small forced labour camp at the outskirts of Erlangen, presumably providing slave labour for a Siemens plant. ${ }^{41}$ On April 16, 1945, Erlangen was liberated by American troops.

Like most Germans, Meythaler experienced the liberation as the "German Catastrophe.” The downfall of the National Socialist state meant for him immediate dismissal from the University, decreed by the American Military Government. Banned from teaching, researching and practicing medicine, facing the loss of a professorial salary and status, he was offered a job in a toy factory as an unskilled labourer.

While struggling with his dismissal, he learnt about the International Military Tribunal convened to hold captured Nazi leaders accountable for their crimes. Conducted in the Nuremberg Palace of Justice, 21 top officials were tried and sentenced on charges of "crimes against peace," "war crimes" and “crimes against humanity,” legal codes regarded as milestones in the history of International Law. The Nuremberg Doctors' Trial followed. ${ }^{42}$ Twenty-three defendants were accused of "war crimes" and "crimes against humanity" perpetrated in concentration camps, research institutions and mental hospitals. Seven death sentences were handed down, five life imprisonments,

\footnotetext{
39 Friedrich Meythaler, letter to Reich Ministry of Science, Education and Popular Education, July 7, 1944.

40 Ibid., letter Wolfgang Wagner to Eckart Moebius, August 7, 1944.

41 The files only contain a brief reference to this forced labour camp. Our research is ongoing to trace archival material.

42 Angela Ebbinghaus and Klaus Dörner, eds., Der Nürnberger Ärzteprozess und seine Folgen (Berlin, Aufbau, 2001).
} 
four long-term imprisonments and seven acquittals. The hepatitis experiments, including Meythaler's research, were discussed at the Doctors' Trial. ${ }^{43}$ Moreover, the defence lawyer for Karl Brandt, Adolf Hitler's "escort" physician and Reich Commissioner for Sanitation and Health, considered calling Meythaler as an expert witness to testify that hepatitis experiments were neither painful nor lethal. Meythaler declined to appear citing medical reasons. ${ }^{44}$ In addition, he was caught up in his own judicial procedure; that is, with the process of denazification.

The ambitious denazification programme was designed by the Allied powers to remove the vast army of over 8 million National Socialists from office and to impose sanctions upon those inculcated in Nazi beliefs. A series of Allied directives was issued to initiate and secure the path to a stable and peaceable democracy. ${ }^{45}$ Hugely unpopular, the different Allied strategies, and the rapid emergence of the Cold War, limited and finally aborted the efforts. From early 1946 civilian tribunals were set up in each zone of occupation and in each major town, commissioned with the task of examining the comprehensive, often ridiculed Fragebögen (questionnaires) completed by the accused and the documentary evidence submitted. A verdict was then handed down, classifying the status of the accused. They ranged from "Exonerated" and "Followers" to "Lesser Offenders" and then to "Offenders" and "Major Offenders."

Meythaler's denazification in Erlangen lasted several months. Maintaining ignorance and innocence he declared, as did so many Germans after the war, that he was neither an antisemite nor a participant in the persecution of the Jews. Self-defence and lies followed the pattern of an entire generation: "I was shocked to hear of the annihilation of the Jews and the horrific crimes perpetrated in concentration camps after the Allies marched in." ${ }^{\text {6 }}$ He admitted that he knew of the killing of mental patients, adding immediately that as a devout Christian and member of the Catholic Church he had rejected the " euthanasia" programme. As far as his medical services were concerned, he saw no reason to reveal the experiments conducted on the Australian POWs on Crete. Instead he proclaimed, "Wherever my services as a doctor were required, I was only concerned with medical considerations. I never allowed myself to be dictated by Party or State authorities." ${ }^{47}$

\footnotetext{
43 Nürnberg Dokument NO 922, 42.

44 Nürnberg Dokument NO 922, 2.2137.

45 Frederick Taylor, Exorcising Hitler: The Occupation and Denazification of Germany (London: Bloomsbury, 2011); Norbert Frei, Vergangenheitspolitik: Die Anfänge der Bundesrepublik Deutschland und die NS-Vergangenheit (Munich: C.H. Beck, 2012).

46 Letter Meythaler to Spruchkammer, January 25, 1947.
} 
Several statements and affidavits were submitted praising the character and credentials of the accused. Most fell into the category of Persil-Scheine. This term was borrowed from the advertisement of the well-known laundry product Persil, propagating its whiteness and cleanliness. All denazification tribunals were flooded with such whitewashing certificates. Meythaler could rely on this classic example:

In his professional capacity as doctor, Meythaler always took pains to show tolerance and to follow the letter of the human principles of the Geneva Convention. His deep Christian convictions were manifest in his care for sick prisoners of war, regardless of nationality. A thousand times over, Meythaler demonstrated his unflinching professional ethics as a physician. ${ }^{48}$

On June 26, 1947, the tribunal handed down its verdict. Referring only to his membership of the NSDAP and other Nazi organisations, Meythaler was classified as "Follower," a mere "Mitläufer" of National Socialism. "Exonerated" persons and "Followers" represented the bulk of the denazified Germans. They were the first granted the privilege of resuming their positions. The rapid reintegration of doctors and lawyers, judges and academics, teachers and policemen, artists and industrialists in the western zones of occupation secured the continuity of the social conservative elites. It provided a decisive impulse for the restoration process that characterised the emergence of the Federal Republic of Germany.

Meythaler's case is a classic example of the ease of transition from murderous Nazi medicine to post-war medicine in Germany. He was not among the ranks of the most brutal and infamous Nazi doctors who, with the permission of Heinrich Himmler, selected inmates in concentration camps and prisons. The victims of such doctors were subjected to terrible experiments without restraint and most were eventually murdered. Those who survived remained traumatised, suffering from lifelong symptoms. Rather, Meythaler typifies the "ordinary" Nazi doctor. He was one of a vast army of physicians who used the circumstances prevailing in Nazi Germany to further their research and careers. Nazi doctrines, policies and warfare escalated into a "Total War" in which legal barriers, medical constraints and moral concerns were abandoned. In this context, doctors were encouraged and instructed to select test subjects from POW camps and other institutions. Nazi doctors, especially the elite of

47 Ibid.

48 Spruchkammer Erlangen-Stadt, January 1, 1947, Affidavit K.E.S. 
the medical profession, grasped the opportunity to continue and intensify their research, without being held accountable for the suffering they inflicted or the crimes they committed.

After his denazification in 1947 Meythaler was appointed Director at the Second Medical Clinic of the city hospital in Nuremberg. One year later he was re-installed as Professor for Internal Medicine at the University of Erlangen. Over the next two decades he distinguished himself again as physician, teacher and researcher, leaving behind a plethora of books, book chapters, edited and co-edited volumes, journal articles and papers. ${ }^{49}$ After pioneering wartime research on malaria, ${ }^{50}$ he moved into a new field—cancer research. ${ }^{51}$ In the early 1950s he founded the Scientific Doctors' Conference, which emerged as a key centre of medical training and education. Later he joined, again as devout Catholic, the chorus of German physicians protesting against the distribution of the "Anti-Baby Pill." He loved and cared for his children, some of whom followed in the footsteps of their father, embarking on medical careers. Aged 69, Friedrich Meythaler died in 1967 in Erlangen. Obituaries paid homage to his life and achievements without mentioning the experiment on Crete or his links to National Socialism. One oration- "In Memoriam Friedrich Meythaler"-published in the medical journal Bayerisches Ärzteblatt, summed up his personality in this way:

It would be difficult to characterize his personality in a few words. He was a man of contradictions. Outwardly he appeared to be a tough guy ("harter Typ”) with fast but sound judgement; his inward response was one of help and care, whenever the sick were in need. ${ }^{52}$

49 To name a few of Meythaler's publications, several of which were co-authored: The Viruspneunomie des Menschen (1952); Prophylaxe. Früherkennung und vorbeugende Therapie innerer Erkrankungen (1950); Die Erkrankungen der Leber-und Gallenwege: Ein Grundriss für Ärzte und Studierende (1957); Die Indikation zur Splenektomie. Mit besonderer Berücksichtigung der splenomegalen Leberzirrhose (1960).

50 Friedrich Meythaler, Differentialdiagnose und Therapie der Malariagruppe im Kriege (Stuttgart: Hippocrates, 1944).

51 Friedrich Meythaler and H. Truckenbrodt, “Körpereigene Abwehr und Krebs,” Ärztliche Praxis 1, no. 2 (1963); Friedrich Meythaler, E. Holder and R. du Mesnil de Rochemont, eds., Therapie maligner Tumore, Hämoblastome and Hämoblastosen, Bd.1: Die operative Behandlung der Geschwülste. Bd.2: Pathologie and Chemotherapie (Stuttgart: Enke, 1968).

52 Bayerisches Ärzteblatt 23, no. 1 (1968), 16. 